\title{
MJMR ANALYSIS OF MATERNAL AND PERINATAL LABOUR COMPLICATIONS WITH MOTHER WHO HAVE GESTATIONAL DIABETES MELLITUS
}

\author{
Desi Sarli", Husni \\ Midwifery of Alifah Academy Padang, Indonesia \\ *Corresponding Author's Email: desi_sarli@yahoo.com
}

\begin{abstract}
Gestational diabetes mellitus is a metabolic disorder caused by mild or severe carbohydrate intolerance, which is first known during pregnancy. Gestational Diabetes Mellitus (GDM) increases maternal, fatal and perinatal morbidity and mortality and increases the risk of developing DM. Epidemiological data show $14 \%$ of pregnancies accompanied by gestational diabetes mellitus. The purpose of this study was to analyse the incidence of maternal and perinatal labour complications in mothers with gestational diabetes.

The type of research carried out is analytical research with Case Control research design. The population of this study was all women who gave birth in the city of Padang Hospital in 2017, with a total sample of 65 mothers with no diabetes mellitus, and 65 samples of mothers with diabetes mellitus. Research implementation \pm 6 months. The data obtained are secondary data, where the data is obtained from the 2017 Labour Medical Record data at Padang City Hospital. Data analysis using univariate analysis, bivariate analysis and multivariate analysis with Multiple Linear Regression Analysis.

The results showed univariate analysis at age: No risk 104 people $(80 \%)$ and at risk 26 people (20\%), Gravida: Primiparous 46 people (35.4\%), Multiparous 64 people (49.2), grandemultiparous 20 people (15.4), Maternal Labor Complication: Normal 58 people (44.6\%), Complications 72 people (55.4\%), Perinatal Labor Complication: Normal 92 babies (70.8\%), Complications 38 babies (29. 2\%), Infant Weight: range 2500-3500 grams as many as 93 babies $(71.5 \%),>3500$ grams as many as 19 babies (14.6\%), <2500 grams 18 babies (13.8\%), average Maternal weight is $66.70 \mathrm{~kg}$. There was no relationship between Gestational Diabetes with age $p$ value $=0.661$, there was no relationship between Gestational Diabetes and Parity $p$ value $=0.798$, there was no relationship between Gestational Diabetes and Maternal Weight $p$ value $=0.190$, there is a relationship between Gestational diabetes and infant weight obtained $p$ value $=0.039$. There was a relationship between Gestational Diabetes and Complication of Maternal Labor $p$ value $=0.000$, There is a relationship between Gestational Diabetes and Complication of Pernatal Labor with $p$ value $=0.054$. There is interaction between Gestational Diabetes and Complication of Maternal Labor with OR value in maternal labor complication $=2.904$.

From the results of the study, it can be concluded that mothers with gestational diabetes have 2.9 times the chance of experiencing complications in childbirth. Therefore, you should be able to do a GDM screening examination, and pregnant women can plan for childbirth and prevent childbirth complications to reduce maternal and infant mortality.
\end{abstract}

\section{Keywords: Diabetes Gestasional Mellitus, Complications of Labor in Maternal and Perinatal}

\section{INTRODUCTION}

Gestational diabetes mellitus (GDM) is a disorder of glucose tolerance that was first discovered during pregnancy. GDM is a condition in women who have not previously been diagnosed with diabetes and then show high glucose levels during pregnancy. Gestational diabetes mellitus is closely related to complications during pregnancy such as increased demand for cesarean section, increased risk of ketonemia, preeclampsia and urinary tract infections, and increased perinatal disorders (macrosomia, neonatal hypoglycemia, and neonatal jaundice). The long-term effect of GDM on infants is an intrauterine environment that is genetically at risk for obesity and/or diabetes; for mothers, GDM is a strong risk factor for permanent diabetes mellitus (Kurniawan, 2016).

Epidemiological data show 14\% of pregnancies accompanied by gestational diabetes mellitus. This is with a family history of type 2 diabetes mellitus. Approximately 60 million women of childbearing age (18-44 years) worldwide suffer from diabetes at this time. Three million women are in America and this 
figure is expected to increase by 2030 . The incidence of diabetes at pregnancy increased by $\pm 40 \%$ between 1989 and 2004. Approximately 700,000 give birth in the UK each year, $5 \%$ of whom have a history of diabetes. More than 179,000 (4.2\%) women in America are pregnant while suffering from DM, about $87.5 \%$ of women who suffer from diabetes during pregnancy are GDM(Cunningham et al., 2018).

Based on the ADA guidelines, each patient must evaluate the risk factors during the first visit. Patients are categorized in high risk if they have at least one of the following criteria: real obesity, history of previous GDM or glucose intolerance or glucosuria, and a family history of type $2 \mathrm{DM}$. While patients will be categorized as low risk if they meet all the following criteria: age $<25$ years, normal pre-pregnancy weight, not ethnic / race with a high prevalence of diabetes (Hispanic American, Native American, Asian American, African American or Pacific Islander), no have a family history of diabetes, no history of glucose intolerance, and do not have poor obstetric outcomes. If it is not included in both, then the patient is categorized as moderate risk. In high-risk patients, blood glucose checks must be carried out as soon as possible. If the results are negative, then this patient must undergo a repeat examination at 24-28 weeks of gestation.

During early pregnancy, glucose tolerance is normal or slightly elevated and peripheral (muscle) sensitivity to insulin and normal hepatic basal glucose production due to increased maternal estrogen and progesterone hormones in early pregnancy which increases pancreatic $\beta$ cell hyperplasia, thereby increasing insulin release. This explains the rapid increase in insulin in early pregnancy in response to insulin resistance.(Rahmawati, Natosba \& Jaji, 2016).

In the second and third trimesters, an increase in fetomaternal relationships will reduce maternal insulin sensitivity so that it will stimulate maternal cells to use energy other than glucose such as free fatty acids, maternal glucose will then be transferred to the fetus. In normal conditions, fetal blood glucose levels are 10$20 \%$ lower than that of mothers, so glucose transport from the placenta to fetal blood can occur through a simple or facilitated diffusion process (Kurniawan, 2016).

During pregnancy, body insulin resistance increases three times compared to nonpregnancy conditions. In pregnancy, decreased insulin sensitivity is characterized by a post-receptor defect that decreases insulin's ability to mobilize SLC2A4 (GLUT 4) from the cell to the cell surface. This may be due to an increase in hormones associated with pregnancy. Although pregnancy is associated with an increase in $\beta$ cell mass and an increase in insulin levels, some women cannot increase insulin production relative to increased insulin resistance, thus becoming hyperglycemic and suffering from GDM (Kurniawan, 2016).

Based on the background described, the researchers were interested in examining the analysis of maternal and perinatal labor complications in gestational diabetes.

\section{METHODOLOGY}

The type of research carried out is analytical research with Case Control research design. The population of this study was all mothers giving birth with gestational diabetes and non-gestational diabetes in 2017 at the Padang City Private Hospital. Sampling with random sampling technique that met the criteria:

a.There is complete data on Maternal and Infant Medical Record Labor History,

b.Mother has been diagnosed with Gestational diabetes,

c.The existence of laboratory supporting data on Gestational Diabetes.

The case group in this study were 65 women who were diagnosed with Gestational Diabetes Mellitus as many as 65 people, while the control group in this study were normal labor as many as 65 people. This research was conducted in Rasidin Padang Hospital and Bhayangkara Hospital, with an estimated time of 6 months. The data used are secondary data obtained from the Medical Record Rasidin Padang Hospital, Bhayangkara Hospital, the mother gave birth to Gestational Diabetes.

Data analysis used is bivariate analysis to determine the relationship between the independent variable and the dependent variable by using the chy-square test with computerization to assess the significance used the significance limit of $25 \%=0.25$ so that the conclusion can be drawn: If the $p$ value is $\leq 0.25$ then $\mathrm{Ha}$ is accepted and $\mathrm{HO}$ is rejected. It means that there is a relationship between the independent variable and the dependent variable. If the $p$ value is Value $>0.25$, Ha is rejected and $\mathrm{HO}$ is accepted, it means there is no relationship between the independent variable and the dependent variable. Data were also analyzed using multivariate analysis with multiple linear regression analysis with a significance limit of $5 \%=0.05$. 


\section{RESULTS}

This research was conducted at Dr. Rasidin Padang Hospital, and Bhayangkara Hospital. The sampling technique was taken in the GDM case group as many as 65 people and in the control group as many as 65 people. Retrieval of data from 2017 labour medical records and tabulated according to the characteristics of each variable and obtained the following research results:

\section{Bivariate Analysis}

Table 1: Relationship of Maternal Weight with Gestational Diabetes Mellitus

\begin{tabular}{|c|c|c|}
\hline $\begin{array}{c}\text { Diabetes } \\
\text { Mellitus }\end{array}$ & $\begin{array}{c}\text { Maternal Weight } \\
\text { Mean } \pm \text { SD }\end{array}$ & p value \\
\cline { 1 - 2 } Non DM & $66.5 \pm 9.35 \mathrm{~kg}$ & \multirow{2}{*}{0.193} \\
\hline DM & $67.88 \pm 11.06 \mathrm{~kg}$ & \\
\hline
\end{tabular}

Based on Table 1, the average maternal weight in Diabetes Mellitus is $67.88 \mathrm{Kg}$. Statistical test results obtained $p$ value is 0.25 which means that there is a relationship between the weight of the mother with Diabetes Mellitus and those who do not have Diabetes Mellitus.

Table 2: Relationship of Maternal Age to Gestational Diabetes Mellitus

\begin{tabular}{|l|c|c|c|}
\hline \multirow{2}{*}{$\begin{array}{l}\text { Diabetes } \\
\text { Mellitus }\end{array}$} & \multicolumn{2}{|c|}{ Maternal Age } & Total \\
\cline { 2 - 4 } & Not at Risk & at Risk & \\
\cline { 2 - 4 } & $\boldsymbol{f}$ & $\boldsymbol{f}$ & \\
\hline Non DM & 53 & 12 & 65 \\
\hline DM & 51 & 14 & 65 \\
\hline Total & 104 & 26 & 130 \\
\hline
\end{tabular}

Pvalue $=0.661$

Based on table 2 it can be seen that out of the 65 respondents who experienced GDM there were 14 people who were at risk ( $<20$ years or $>35$ years). In the results of statistical tests, it was obtained $p$ value $\geq 0.25$ so that it can be said that there was no significant relationship between maternal age and the incidence of diabetes mellitus gestasional.
Table 3: Parity Relationship with Gestational Diabetes Mellitus

\begin{tabular}{|l|c|c|c|c|}
\hline \multirow{2}{*}{$\begin{array}{c}\text { Diabetes } \\
\text { Mellitus }\end{array}$} & \multicolumn{3}{|c|}{ Parity } & Total \\
\cline { 2 - 4 } & $\boldsymbol{f}$ & $\boldsymbol{f}$ & $\boldsymbol{f}$ & \\
\cline { 2 - 5 } & Primiparous & Multiparous & $\begin{array}{c}\text { Grande- } \\
\text { multiparous }\end{array}$ & \\
\hline Non DM & 22 & 35 & 8 & 65 \\
\hline DM & 24 & 29 & 12 & 65 \\
\hline Total & 46 & 64 & 20 & 130 \\
\hline
\end{tabular}

$P$ value $=0.758$

Based on table 3 it can be seen that out of 65 respondents who experienced GDM there were 29 people who had multiparous parity (number of children 2-4). In the results of statistical tests obtained $p$ value $\geq 0.25$ so it can be said that there is no significant relationship between parity and the incidence of Diabetes Mellitus Gestasional.

Table 4: Relationship of Infant Weight with Gestational Diabetes Mellitus

\begin{tabular}{|l|c|c|c|c|}
\hline \multirow{2}{*}{$\begin{array}{l}\text { Diabetes } \\
\text { Mellitus }\end{array}$} & \multicolumn{3}{|c|}{ Infant Weight } & Total \\
\cline { 2 - 4 } & $<\mathbf{2 5 0 0}$ & $\mathbf{2 5 0 0 - 3 5 0 0}$ & $\mathbf{3 5 0 0}$ & \\
\cline { 2 - 4 } & $\boldsymbol{f}$ & $\boldsymbol{f}$ & $\boldsymbol{f}$ & \\
\hline Non DM & 22 & 35 & 8 & 65 \\
\hline DM & 24 & 29 & 12 & 65 \\
\hline Total & 46 & 64 & 20 & 130 \\
\hline
\end{tabular}

Based on the table 4 out of 65 mothers who have diabetes mellitus obtained a baby's weight $<2500$ grams as many as 24 babies and $>3500$ grams as many as 12 babies. The results of statistical tests obtained $p$ value $\leq$ 0.25 which means there is a relationship between the weight of the baby and the incidence of diabetes. 
Table 5: The relationship between Maternal Labour Complications and Gestational Diabetes Mellitus

\begin{tabular}{|l|c|c|c|}
\hline \multirow{2}{*}{$\begin{array}{c}\text { Diabetes } \\
\text { Mellitus }\end{array}$} & \multicolumn{2}{|c|}{$\begin{array}{c}\text { Maternal Labor } \\
\text { Complication }\end{array}$} & \multirow{2}{*}{ Total } \\
\cline { 2 - 3 } & Normal & Complication & \\
\cline { 2 - 3 } & $\boldsymbol{f}$ & $\boldsymbol{f}$ & \\
\hline Non DM & 39 & 26 & 65 \\
\hline DM & 19 & 46 & 65 \\
\hline Total & 58 & 72 & 130 \\
\hline
\end{tabular}

Pvalue $=0.000$

Based on the table 5 out of 65 mothers who experienced diabetes mellitus found mothers had 46 maternal labour complications. The results of statistical tests obtained $P$ value of $\leq 0.25$ which means that there is a relationship between complications of maternal labour with diabetes mellitus.

Table 6: The Relationship of Perinatal Labor Complications with Gestational Diabetes Mellitus

\begin{tabular}{|l|c|c|c|}
\hline \multirow{2}{*}{$\begin{array}{l}\text { Diabetes } \\
\text { Mellitus }\end{array}$} & \multicolumn{2}{|c|}{$\begin{array}{c}\text { Perinatal Labor } \\
\text { Complication }\end{array}$} & \multirow{2}{*}{ Total } \\
\cline { 2 - 3 } & Normal & Complication & \multirow{2}{*}{} \\
\cline { 2 - 3 } & $\boldsymbol{f}$ & 14 & 65 \\
\hline Non DM & 51 & 24 & 65 \\
\hline DM & 41 & 38 & 130 \\
\hline Total & 92 & & \\
\hline
\end{tabular}

$P$ value $=0.05$
Based on table 6 of 65 mothers who experienced Gestational Diabetes Mellitus were found who experienced labor complications in perinatal as many as 24 infants. The results of statistical tests obtained $p$ value of $\leq 0.25$ which means there is a relationship between perinatal labor complications with Gestational Diabetes Mellitus.

\section{Multivariate Analysis}

In conducting multivariate analysis, bivariate selection, multivariate modeling, and interaction test between independent variables related to the dependent variable must be carried out. Bivariate analysis $p$ value $\leq 0.25$, there is a relationship, while multivariate analysis $p$ value $\leq 0.05$ has influence.

\section{Bivariate Selection}

Table 7: Results of Bivariate Selection

\begin{tabular}{|l|c|}
\hline Variable & P value \\
\hline Maternal Weight & 0.190 \\
\hline Maternal age & 0.661 \\
\hline Parity & 0.798 \\
\hline Infant Weight & 0.039 \\
\hline $\begin{array}{l}\text { Maternal Labor } \\
\text { Complication }\end{array}$ & 0.000 \\
\hline Perinatal Labor & 0.050 \\
\hline Complication & \\
\hline
\end{tabular}

From table 7 it is known that the variables included in the multivariate analysis are maternal weight, infant weight, complications of maternal labour and complications of perinatal labor.

\section{Multivariate Analysis}

Table 8: Effect of Maternal Weight Variables, Infant Weight, Complications of Maternal Labor and Complications of Perinatal Labor on Gestational Diabetes Mellitus

\begin{tabular}{|c|c|c|c|c|c|c|c|c|}
\hline & \multirow[b]{2}{*}{$B$} & \multirow[b]{2}{*}{ S.E. } & \multirow[b]{2}{*}{ Wald } & \multirow[b]{2}{*}{$D f$} & \multirow[b]{2}{*}{ Sig. } & \multirow[t]{2}{*}{$\operatorname{Exp}(B)$} & \multicolumn{2}{|c|}{$95 \%$ CI for $\operatorname{Exp}(B)$} \\
\hline & & & & & & & Lower & Upper \\
\hline Maternal Weight & 0.018 & 0.019 & 0.869 & 1 & 0.351 & 1.018 & 0.980 & 1.057 \\
\hline Infant Weight & 0.295 & 0.310 & 0.902 & 1 & 0.342 & 1.343 & 0.731 & 2.467 \\
\hline $\begin{array}{l}\text { Maternal Labor } \\
\text { Complication }\end{array}$ & 1.066 & 0.409 & 6.780 & 1 & 0.009 & 2.904 & 1.302 & 6.480 \\
\hline $\begin{array}{l}\text { Perinatal Labor } \\
\text { Complication }\end{array}$ & 0.101 & 0.486 & 0.043 & 1 & 0.836 & 1.106 & 0.426 & 2.869 \\
\hline
\end{tabular}


From table 8 it can be seen that the independent variables are related to the dependent variable after multivariate tests obtained $p$ value of each variable. If the independent variable has a $p$ value $\leq 0.05$ then this variable has an influence on the dependent variable. Based on the table it is known: variable complications of maternal labour affect the condition of GDM mothers with $p$ value $=0.009$. Gestational Diabetes Mellitus affects Complications of Labor in Maternal with $\mathrm{OR}=2.904$. This means that the complications of maternal labour will occur 2.9 times in women who have gestational diabetes mellitus.

\section{Interaction Test}

The interaction test was carried out on variables that were suspected to have interactions in this study, it was suspected that maternal labor complications interacted with the condition of mothers who had diabetes mellitus. The results of the interaction test can be seen in the table below:

Table 9: Results of the Complication Interaction of Maternal Childbirth and Gestational Diabetes Mellitus

\begin{tabular}{|l|c|c|c|}
\hline & Chi-Square & Df & Sig. \\
\hline Step 1 & 13.649 & 2 & 0.001 \\
Block & 13.649 & 2 & 0.001 \\
Model & 13.649 & 2 & 0.001 \\
\hline
\end{tabular}

Based on table 9 it is known that the results of the interaction test for maternal labour complications and the incidence of diabetes mellitus obtained $p$ value $=$ 0.001 means that $p$ value $\leq 0.05$ so the decision of the interaction variable is significant, meaning: there is an interaction between the incidence of maternal labour complications with the incidence of gestational diabetes mellitus.

\section{DISCUSSION}

\section{Bivariate Analysis}

\section{Relationship of Maternal Weight with Gestational} Diabetes Mellitus

Based on Table 1, the average maternal weight in Diabetes Mellitus is $67.88 \mathrm{Kg}$. Statistical test results obtained $p$ value is 0.25 which means that there is a relationship between the weight of the mother with Diabetes Mellitus and those who do not have Diabetes Mellitus. Based on research by Kurniasari and others with the title of the study, the description of the condition of pregnant women with diabetes mellitus in the hospital Dr. Soebandi Jember, shows the results of the study of body weight in pregnant women with overweight BMI (23-24.9 kg / m2), as many as 11 patients $(57.9 \%)$ of a total of 19 patients. Meanwhile, pregnant women with a normal BMI $(18.5-22.9 \mathrm{~kg} /$ $\mathrm{m} 2$ ) were 8 patients $(42.1 \%$ ) (Kurniasari \& Arifandini, 2015).

Obesity is the main agent and factor that causes pregnant women with diabetes mellitus. Subcutaneous and visceral fats in the body of expectant pregnant women with obesity will produce adipocytokine hormones that fight insulin action. Women who have excessive fat on the torso, especially if it's in the abdomen, are more likely to develop diabetes that is not insulin dependent. This is because the fat in the abdominal organs seems to be more easily processed to obtain energy. When fat is processed to obtain energy, the level of fatty acids in the blood increases. The high level of fatty acids in the blood increases insulin resistance through its action on the liver and muscles of the body. 9 Obese women are at risk of developing GDM during pregnancy(Wahyuni \& Alkaff, 2013).

\section{Relationship of Maternal Age to Gestational Diabetes Mellitus}

Based on table 2 it can be seen that out of the 65 respondents who experienced GDM there were 14 people who were at risk ( $<20$ years or $>35$ years). In the results of statistical tests, it was obtained $p$ value $\geq 0.25$ so that it can be said that there was no significant relationship between maternal age and the incidence of diabetes mellitus gestasional.

Based on research by Dyah et al., (2018) entitled about the description of the condition of pregnant women with diabetes mellitus in the hospital Dr. Soebandi Jember with the results of research on the age of mothers who have a high risk of $52.6 \%$ and the age of mothers who are not at risk as much as $47.4 \%$.

Whereas based on the entitled Hypertension and Diabetes Mellitus in Fertile Age Women in Urban Areas in Indonesia with the results of the 15-19 years age group as much as $0.6 \%, 20-34$ years as much as $5.2 \%$, more than 35 years as many as $22.7 \%$ in cases of Diabetes Mellitus (Delima, Isnawati \& Raini, 2012). According to Wahyuni's (2013) study, there was 3.6 percent of DM patients in women of reproductive age.

Diabetes mellitus is a disease that occurs due to a decrease in the function of the body's organs (degenerative), especially disorders of the pancreas organ in producing the hormone insulin so that GDM 
will increase its case in line with age(Dyah et al., 2018).

\section{Parity Relationship with Gestational Diabetes Mellitus}

Based on table 3, it can be seen that out of 65 respondents who experienced GDM there were 29 people who had multiparous parity (number of children $2-4)$. In the results of statistical tests obtained $p$ value $\geq$ 0.25 so it can be said that there is no significant relationship between parity and the incidence of Diabetes Mellitus Gestasional.According to Ali's (2018) study, the parity of maternal with gestational diabetes who were undergoing dietary treatment was in primipara as many as $35(25.4 \%)$ and in multiparous as many as $103(74.6 \%)$ with $p$ value $=0.278$.

According to Wilda's research (2015) that parity is a risk factor for the incidence of GDM in pregnancy, it can be interpreted that the OR value of 0.443 means that mothers with multiparous parity have a tendency to experience DM in pregnancy as much as 0.443 times as one of the factors associated with diabetes mellitus in pregnancy compared with respondents with primiparous parity. In accordance with the theory put forward by (Prawirohardjo, 2010), parity 2-3 is the safest parity in terms of maternal mortality. Parity 1 and high parity (more than 3 ) have a higher maternal mortality rate. The higher maternal parity, the less good the endometrium will be, this is caused by reduced vascularization or atrophic changes in the decidua due to past labor, which can lead to labor complications.

This theory is also supported by the theory proposed by (Permatasari, 2017) also states that in old age lifestyle changes occur, ranging from diet/type of food consumed to reduced physical activity. This occurs especially in the adult and above groups in all socioeconomic statuses. The higher the age, the more risk to suffer from gestational diabetes mellitus prediabetes, therefore, mothers need to avoid pregnancy at a high risk age.

During pregnancy, body insulin resistance increases three times compared to nonpregnancy conditions. In pregnancy, decreased insulin sensitivity is characterized by a post-receptor defect that decreases insulin's ability to mobilize SLC2A4 (GLUT 4) from the cell to the cell surface. This may be due to an increase in hormones associated with pregnancy. Although pregnancy is associated with an increase in $\beta$ cell mass and an increase in insulin levels, some women cannot increase insulin production relative to increased insulin resistance, thus becoming hyperglycemic and suffering from GDM(Kurniawan, 2016).

\section{Relationship of Infant Weight with Gestational Diabetes Mellitus}

Based on the table 4 out of 65 mothers who have diabetes mellitus obtained a baby's weight $<2500$ grams as many as 24 babies and $>3500$ grams as many as 12 babies. The results of statistical tests obtained $p$ value $\leq 0.25$ which means there is a relationship between the weight of the baby and the incidence of diabetes.

According to Ali's (2018) study, the results showed that mothers with gestational diabetes would have a risk of giving birth to macrosomic babies 2.05 times with a $p$ value of 0.014

According to Fitriani's research (2017) with the results of the study of mothers who had gestational diabetes gave birth to macrosomic babies at $78.1 \%$ with a $p$ value $=0.006$. Gestational diabetes mellitus (GDM) is an important risk factor in the development of fetal macrosomia because hormonal and metabolic changes occur during pregnancy, which is marked by an increase in glucose levels in the blood and an increase in estrogen and progestin hormones resulting in an abnormal number or function of insulin. the effect of insulin causes high blood sugar levels of pregnant women so that gestational diabetes occurs. This situation can have an impact on the fetus that causes hyperglycemia in the uterine environment so that babies born to mothers who experience gestational diabetes mellitus are at high risk for macrosomia (Rahayu \& Rodiani, 2016)

\section{The Relationship between Maternal Labor Complications and Gestational Diabetes Mellitus}

Based on the table 5 out of 65 mothers who experienced diabetes mellitus found mothers had 46 maternal labour complications. The results of statistical tests obtained $P$ value of $\leq 0.25$ which means that there is a relationship between complications of maternal labour with diabetes mellitus. Based on the results of the research Dyah et al (2018) stated that mothers with gestational diabetes mellitus had a history of preeclampsia of $57.9 \%$.

Diabetes mellitus has a substantial increase in risk for the mother and fetus. The risk to the mother includes damage to the retina, kidneys, heart, urinary tract infections, diabetic ketoacidosis and cesarean section. Hypertension is common and diabetic women with 
kidney disease are at high risk of developing preeclampsia. This opinion is also reinforced that gestational diabetes mellitus is a metabolic disorder in mild pregnancies, but mild hyperglycemia can provide complications for the mother in the form of preeclampsia. This is possible because of a previous history of pre-eclampsia for multiparous and grandemultipara pregnant women, namely in pregnancies that previously had a history of preeclampsia so that the risk of pre-eclampsia for subsequent pregnancies is at risk(Dyah et al., 2018).

\section{The Relationship of Perinatal Labor Complications with Gestational Diabetes Mellitus}

Based on table 6 of 65 mothers who experienced Gestational Diabetes Mellitus were found who experienced labor complications in perinatal as many as 24 infants. The results of statistical tests obtained $p$ value of $\leq 0.25$ which means there is a relationship between perinatal labor complications with Gestational Diabetes Mellitus.

According to Istiyana's study (2016) showed that there was a significant relationship between pre-gestational diabetes mellitus mothers with the risk of cleft lip and palate infants $(p<0.05, \mathrm{OR}=6.143,95 \%$ CI $[1.806$, 20.897]).The risks associated with gestational diabetes are pre-natal morbidity and mortality and an increase in cesarean delivery and chronic hypertension in the mother. Women with gestational diabetes are more likely to give birth to a large baby which is the reason why more women with gestational diabetes have a cesarean delivery. Women with diabetes before pregnancy are more likely to have babies with congenital defects if their glycemic control is below optimal during the first trimester of pregnancy. Thus it is very important for all women with diabetes to be counseled about the risk of hyperglycemia and pregnancy before conception and for women with diabetes to plan their pregnancy so as to reduce the risk of congenital defects in their offspring. Up to $50 \%$ of women with gestational diabetes continue to develop into type 2 diabetes (Wahyuni \& Alkaff, 2013).

\section{Multivariate Analysis}

From table 7 it is known that the variables included in the multivariate analysis are maternal weight, infant weight, complications of maternal labour and complications of perinatal labour. From table 8 it can be seen that the independent variables are related to the dependent variable after multivariate tests obtained $p$ value of each variable. If the independent variable has $p$ value $\leqslant 0.05$ then this variable has an influence on the dependent variable. Based on the table, it is known: variable maternal labour complications affect the condition of DM women with $p$ value $=0.009$.

The interaction test was carried out on variables that were suspected to have interactions in this study, it was suspected that maternal labour complications interacted with the condition of mothers who had diabetes mellitus. Based on table 9 it is known that the results of the interaction test for maternal labour complications and the incidence of diabetes mellitus obtained $p$ value $=0.001$ means that $p$ value $\leqslant 0.05$ so that the decision of interaction variables is significant. It means that there is an interaction between the incidence of maternal labour complications with the incidence of diabetes mellitus with $\mathrm{OR}=2.904$. This means that the complications of maternal labour will occur 2.9 times in mothers who have diabetes mellitus.

\section{CONCLUSION}

From the results of research that has been done can be drawn conclusion as follows: there was a significant relationship between maternal weight and gestational diabetes mellitus, there was no significant relationship between maternal age and the incidence of gestasional diabetes mellitus. There was no significant relationship between parity and the incidence of gestasional diabetes mellitus. There was a relationship between infant weight and gestasional diabetes mellitus. There was a relationship between maternal labor complications and incidence Gestasional Diabetes mellitus, there is a relationship between perinatal labor complications with Gestasional Diabetes Mellitus. Complications of maternal labor will occur 2.9 times in women who have gestational diabetes mellitus.

\section{REFERENCES}

Ali, A., Shastry, S., Nithiyananthan, R., Ali, A. \& Ganapathy, R. (2018). Gestational diabetes-Predictors of response to treatment and obstetric outcome. European Journal of Obstetrics Gynecology and Reproductive Biology, 220, pp 57-60.

Cunningham, F.G., Leveno, K., Bloom,S., Spong,C., Dashe,J., Hoffman,B. \& Casey, B. (2018). Wiilliams Obstetrics. $25^{\text {th }}$ Edition, Mc Graw Hill, USA

Delima, I., A. \& Raini, M. (2012). Hipertensi dan Diabetes Mellitus pada Wanita Usia Subur (WUS) di Daerah Urban di Indonesia. Jurnal Biotek Medisiana Indonesia, 1(1), pp 41-53. 
Dyah, M., Tito, M., Wahjudi, P. \& Prasetyowati, I. (2018). Gambaran Kondisi Ibu Hamil dengan Diabetes Mellitus di RSD dr. Soebandi Jember Tahun 20132017 ( Description of Pregnant Women Condition with Diabetes Mellitus in RSD dr . Soebandi Jember on 2013-2017 ). E-Jurnal Pustaka Kesehatan, 6 (1), pp 46-52.

Fitriani, R. (2017). Analisis Faktor Resiko Kejadian Diabetes Melitus Gestasional di Wilayah Kerja Puskesmas Kecamatan Somba OPU Kabupaten GOWA Tahun 2016. Molucca Medica, 10(1), pp 110-126.

Istiyana, D. T., Hartoyo, E. \& Bayu, I. S. (2016). Hubungan Antara Ibu Penderita Pre-Gestasional Diabetes Mellitus Dengan Risiko Kelahiran Bayi Cleft Lip and Palate. Jurnal Kedokteran Gigi, 1(1), pp 32-36.

Kurniasari, D. \& Arifandini, F. (2015). Hubungan Usia, Paritas Dan Diabetes Mellitus Pada Kehamilan Dengan Kejadian Preeklamsia Pada Ibu Hamil Di Wilayah Kerja Puskesmas Rumbia Kabupaten Lampung Tengah Tahun 2014. Holistik Jurnal Kesehatan, 9(3), pp 142-150.

Kurniawan, L. B. (2016). Patofisiologi, Skrining, dan
Diagnosis Laboratorium Diabetes Melitus Gestasional. Tinjauan Pustaka, 43(11), pp 811-813.

Permatasari, I. I. M. (2017). The Correlation Between Hypertension And Overweight In Pregnant Women In The Operational Area. Sekolah Tinggi Ilmu Kesehata Muhammadiyah Samarinda.

Prawirohardjo, S. (2009). Ilmu Kebidanan. $4^{\text {th }}$ Edition, Jakarta :Yayasan BinaPustaka Sarwono Prawirohardjo.

Rahayu, A. \& Rodiani. (2016). Efek Diabetes Melitus Gestasional terhadap Kelahiran Bayi Makrosomia. Majority, 5(4), pp 17-22.

Rahmawati, F., Natosba, J. \& Jaji. (2016). Skrining Diabetes Mellitus Gestasionaldan Faktor Risiko Yang Mempengaruhinya. Jurnal Keperawatan Sriwijaya, 3(2), pp 33-43.

Wahyuni, S. \& Alkaff, R. N. (2013). Diabetes Mellitus Pada Perempuan Usia Reproduksi Di Indonesia Tahun 2007. Jurnal Kesehatan Reproduksi, 3(1), pp 46-51.

Wilda Silvia Nora, E. M. (2015). Faktor Resiko Kejadian Diabetes Melitus dalam Kehamilan pada Ibu Hamil di Rumah Sakit Ibu dan Anak tahun 2014, 67 